\title{
STUDI EKSEGETIS UNGKAPAN \\ MENGUCAP SYUKUR DALAM SEGALA HAL \\ MENURUT 1 TESALONIKA 5:18
}

David Susilo Pranoto

davidsusilopranoto@.ac.id

\begin{abstract}
Abstarksi: Give thanks is an attitude of the human heart. Giving thanks shows an attitude that is based on a believer's faith in God. Even though this is a simple command, reality shows many believers' failure to give thanks. The Apostle Paul also saw this reality, therefore through 1 Thessalonians, the apostle Paul wanted to give teachings and appeals so that the believers in Thessalonica could show an attitude of life to give thanks. But there are different things that Paul taught with the concept of thanksgiving of unbelievers. Therefore, to understand these differences, it is very important to study thanksgiving from a biblical perspective, in this article specifically doing the exegetical study of the expression "giving thanks in all things" according to 1 Thessalonians 5:18.
\end{abstract}

Keywords: $\quad$ Exegetical Study, Gratitude, All Things.

Abstarksi: $\quad$ Mengucap syukur adalah sebuah sikap hati manusia. Mengucap syukur menunjukkan sebuah sikap yang didasarkan pada iman orang percaya kepada Allah. Sekalipun ini sebuah perintah sederhana, namun realitas menunjukkan banyak kegagalan orang percaya untuk mengucap syukur. Rasul Paulus juga melihat realitas demikian, oleh karena itu melalui Surat 1 Tesalonika, rasul Paulus ingin memberikan pengajaran dan himbauan agar orang percaya di Tesalonika dapat menunjukkan sikap hidup mengucap syukur. Namun ada hal-hal yang berbeda yang Paulus ajarkan dengan konsep ucapan sykur orang yang tidak percaya. Oleh karena itu untuk mengerti perbedaan tersebut, maka sangat penting mempelajari ucapan sykur dari perspektif Alkitab, dalam artikel ini secara khusus melakukan studi eksegetis ungkapan "mengubcap syukur dalam segala hal" menurut 1 Tesalonika 5:18.

Kata Kunci: Studi Eksegetis, Mengucap Syukur, Segala Hal.

\section{LATAR BELAKANG MASALAH}

Mengucap syukur ialah kita dapat bersyukur kepada Tuhan karena kita mempunyai janji-Nya bahwa walaupun ada banyak kesusahan dan penderitaan, Dia tidak akan pernah melupakan kita."1 Arti penyataan di atas, menunjukkan bahwa Tuhan tidak pernah melupakan umat-Nya, baik dalam kesusahan dan penderitaan yang sedang dialami dalam kehidupan mereka. Dalam hal mengucp syukur orang percaya harus memiliki pemahaman yang benar, Dahlenburg menjelaskan bahwa:

Kita menyadari bahwa berkat Tuhan tidak tergantung pada kemakmuran atau kekayaan kita. Sebaliknya, kadang-kadang kemakmuran dan kekayaan

\footnotetext{
${ }^{1}$ Gerald D. Dahlenburg, Firman Hidup (Jakarta : BPK Gunung Mulia, 2003), 65
} 
menjadi kutuk bagi kita, sama seperti bangsa Yehuda meninggalkan Tuhan waktu mereka makmur. Sebaliknya, kalau kita miskin, sakit atau sendirian, hal ini tidak berarti, Tuhan marah kepada kita atau kurang mengasishi kita. ${ }^{2}$

Dalam hal mengucap syukur sangat jelas bahwa tidak dipandang dari hal kekayaan, karena ketika dipandang dalam kekayaan atau kemakmuran, bisa saja melupakan Tuhan. Seseorang yang mengucap syukur karena ia menyadari berkat-berkat Tuhan dalam dirinya dan tidak hanya bergantung dengan hartanya. Selanjutnya Tan mengatakan bahwa "hati yang bersyukur dan pujian memberi kekuatan untuk mengatasi segala sesuatu." ${ }^{3}$ Dalam perkataan ini dijelaskan bahwa, dengan adanya niat hati untuk bersyukur serta membawa persembahan pujian kepada Tuhan, maka Tuhan bertindak memberi kekuatan kepada umat-Nya, bahkan juga Ia memberi jalan keluar dalam setiap masalah, artinya bahwa Tuhan hadir dalam setiap pergumulan untuk menolong.

Setiap orang yang mengucap syukur kepada Tuhan, akan mendapatkan pertolongan dan kekuatan dari pada-Nya sehingga mampu menghadapi setiap masalah dalam hidupnya. Maukar mengatakan bahwa "Ucapan syukur adalah suatu ekspresi dari iman yang tinggi." Dalam penyataan ini, suatu eskspresinya atau semangat bagian dalam iman seseorang yang semakin giat atau mendorongnya untuk selalu berterimakasih kepada Tuhan. Atau dapat diartikan karena ia percaya kepada Tuhan sehingga ia bersemangat untuk bersyukur dalam hal apapun.

Munthe mengatakan bahwa "dengan mengucap syukur dalam segala hal, berarti kita mengakui kelemahan dan kekecilan serta kemiskinan kita dihadapan Tuhan dan mengakui kebesaran serta kekayaan-Nya." ${ }^{, 5}$ Bersyukur itu merupakan suatu pengakuan terhadap kekayaan Tuhan. Seseorang juga mengucap syukur karena mendapatkan damai sejahtera dari Tuhan, Munthe menjelaskan:

Kita bersukacita sambil berdoa dan kita berdoa sambil mengucap syukur. kita mengucap syukur, karena sukacita yang kita peroleh dari Tuhan dst. Bukan kita lagi berada di dalam "lingkaran Tuhan" yang membawa damai sejahtera dan kebahagiaan bagi kita semuanya. Orang-orang yang berada di dalam "lingkaran setan" biasanya tidak sampai kepada penyelesaian secara positif, karena ada saja alasan yang berputar-putar, di mana satu sama lain tidak mendukung. ${ }^{6}$

Penulis memahami bahwa orang yang mengucap syukur adalah orang yang memperoleh damai sejahtera dalam hidupnya. Izaak mengatakan bahwa "Kehidupan yang

\footnotetext{
${ }^{2}$ Ibid..,65

${ }^{3}$ Daniel Tan, Sistematika Pembinaan Warga jemaat (Manado: Yayasan Daun famili, 2016), 313

${ }^{4}$ Frengky Maukar, Masalah Adalah Berkat (Jakarta Pusat: Internasional Galilea Ministri ,2008), 160

${ }^{5}$ A. Munthe Fiman Hidup (Jakarta: BPK Gunung Mulia, 2002), 45

${ }^{6}$ Ibid. 71
} 
tidak bersyukur adalah kehidupan yang menganggap bahwa segala sesuatu yang ia nikmati dan diterimanya adalah kerena usaha dan kemampuannya."7 Jelas kehidupan orang yang tidak bersyukur atas berkat yang ia miliki selalu menganggap hasil dari jerih payahnya sendiri. Orang Kristen seharusnya juga tahu mengucap syukur dan berterima kasih kepada Tuhan, karena diberikan kesempatan hidup dan juga keselamatan didalam Tuhan Yesus.”, Dalam hal ini, orang percaya mengucap syukur kerena Tuhan masih memberi kesempatan untuk menikmati hidup dan keselamatan. Setiap orang Kristen perlu menggunakan waktu secara maksimal untuk bersyukur kepada Tuhan.

Carothers juga mengatakan bahwa "kita mengucap syukur kepada Allah bukan untuk mendapat hasil-hasil yang diharapkan, tetapi kita mengucap syukur untuk situasi yang ada sebagaimana adanya." Dalam perkataan ini, seseorang yang bersyukur bukan apa yang sedang dipikirkan atau sesuatu yang memang benar-benar diharapkan, akan tetapi mengucap syukur karena situasi berkehidupan. Jelas bahwa memang bersyukur bukan pada saat mendapatkan kebanggaan hidup, tetapi mengucap syukur karena salah satu perintah Tuhan. Seseorang yang mengucap syukur bukan hanya pada tertentu saja.

Menurut Carothers pengucapan syukur atau pujian itu didasarkan pada suatu penerimaan yang penuh dengan sukacita akan hal yang ada ketika itu sebagai dari kehendak Allah yang penuh kasih dan sempurna untuk diri kita. ${ }^{10}$ Pernyataan di atas menjelaskan bahwa pengucapan syukur itu suatu penerimaan yang sungguh-sungguh dengan sukacita. Ferrucci mengatakan bahwa:

Mengucap syukur bukan bergantung pada keberanian, kekuatan, atau talenta. Dalam perkataan ini, seseorang dapat bersyukur bukan adanya keberanian untuk selalu bisa bahkan masih ada kekuatan dalam hal melakukannya atau juga mempunyai karunia sebuah talenta pada diri. Hal itu justru berdasarkan ketidaksempurnaan hidup. Jika kita tidak menyembunyikannya dari diri kita sendiri, kita dapat menerima kebaikan yang diberikan oleh kehidupan kepada kita dan kita dapat bersyukur. Perasaan senang di dalam tindakan bersyukur berasal dari pengakuan bahwa kita tidak dapat mengatur segala sesuatu sendirian, bahwa kita tidak perlu harus menjadi seperti superman atau superwoman, dan meskipun kita bukan orang yang sangat cerdas, kita puas menjadi diri kita sendiri. ${ }^{11}$

\footnotetext{
${ }^{7}$ Sealthie Izaak, Firman Hidup (Jakarta: BPK Gunung Mulia, 2003), 55

${ }^{8}$ Abiyah Publishing, Salam Dan Doa (Jakarta: Do Business Till I Come, 2003), 112

${ }^{9}$ Merlin R. Carothers, Kuasa Dalam Pengucapan Syukur (Jakarta: Kristen Injil Indonesia, 2008), 17

${ }^{10}$ Ibid..,

${ }^{11}$ Piero Ferrucci, Bagaimana Menjadi Orang Baik (Jakarta: PT BPK Gunung Mulia, 2009), 215
} 
Ferrucci mengatakan bahwa menjadi orang yang baik tanpa bersyukur adalah sesuatu yang berbahaya. ${ }^{12}$ Orang yang tidak tahu bersyukur itu orang berbahaya. Stephen Tong mengatakan bahwa "hidup bersyukur merupakan kehendak Allah bagi kita di dalam Kristus."13 Bersyukur itu adalah kehendak Allah. Terkait dengan hal di atas penulis menemukan suatu fakta yang terjadi dalam kehidupan Orang percaya. Penulis mewawancarai salah satu Orang percaya. Orang percaya memahami bahwa mengucap syukur dalam segala hal itu sangat sulit untuk melakukannya. Contohnya jika tidak mempunyai berkat dalam bentuk uang. Orang percaya memahami bahwa mengucap syukur dalam segala hal itu sangat susah untuk melakukannya. Contohnya jika dalam keadaan kesusahan atau penderitaan. Orang percaya memahami bahwa mengucap syukur dalam segala hal itu tidak mudah untuk melakukannya. Contohnya jika keadaan kesusahan dalam bentuk ekomomi.

Penulis memahami bahwa inilah sebuah masalah yang terjadi dalam kehidupan Orang percaya, tentang mengucap syukur dalam segala hal. Oleh karena itu, setiap orang percaya harus memahami tentang mengucap syukur dalam segala hal. Setelah memahami Latar Belakang Masalah di atas, maka perlu dipahami bagaimana perspektif Rasul Paulus tentang Mengucap syukur dalam segala hal berdasarkan 1Tesalonika 5:18 dan Implikasinya bagi orang percaya masa kini.

\section{METODE PENELITIAN}

Metode Penelitian dalam artikel ini menggunakan metode deskriptif analisis, artinya mengumpulkan data untuk memberikan gambaran atau penegasan suatu Perspektif atau gejala yang di dalamnya terdapat upaya mendeskripsikan, mencatat, menganalisis, dan menginterpretasikan kondisi-kondisi yang saat ini terjadi. Selanjutnya metode penelitian literature yang berkaitan dengan pengumpulan informasi yang relevan dengan masalah yang sedang diteliti, mengenai teori-teori dari sejumlah buku-buku literatur, maknamakna, serta temuan-temuan yang berkaitan dengan judul penelitian.

\section{LATAR BELAKANG SURAT 1 TESALONIKA}

Sebelum melakukan eksegese ungkapan "mengucap syukur dalam segala hal menurut" dalam 1Tesalonika 5:18, terlebih dahulu akan dipaparkan tentang latar belakang penulis surat 1Tesalonika, tempat dan waktu penulisan, garis besar surat, tujuan surat dan

\footnotetext{
${ }^{12}$ Ibid.., 219

${ }^{13}$ Stephen Tong, Mengetahui Kehendak Allah (Surabaya: Momentum, 2004), 147
} 
penerima surat. Latar belakang yang menyebabkan Paulus menulis surat 1 Teslonika khususnya 5:18, Paulus menyatakan keinginannya yang paling dalam kepada jemaat di Tesalonika untuk hidup mengucap syukur dalam segala hal.

Jemaat Tesalonika merupakan buah dari pelayanan Paulus ketika dalam pelayanan pemberitaan Injil yang kedua (Kisah Para Rasul 17:1-9), karena diganggu terus oleh orang-orang Yahudi yang di Tesalonika dan Berea (Kisah Para Rasul 17:10-15), Paulus pergi ke Atena untuk menunjukkan keprihatiannya, atas kesejahteraan rohani orang-orang percaya di Tesalonika, sehingga mendorong dia untuk mengutus Timotius untuk menguatkan iman jemaat Tesalonika dalam menghadapi berbagai gelombang penganiayaan. ${ }^{14}$

Sehubungan dengan penjelasan di atas Baxter menjelaskan bahwa hal yang membuat Paulus menulis surat 1Tesalonika adalah terdapat dalam 1Tesalonika 3:6 menjelaskan bahwa:

Kunjungan Tesalonika yang singkat tapi besar hasilnya telah diganggu, Paulus terpaksa melarikan diri karena dilawan oleh orang Yahudi dengan perantaraan para penjahat yang menimbulkan kerusuhan di Kota. Paulus dan pembantunya didakwa sebagai pengkhianat karena pemberitaan 'Raja lain yaitu (Kisah Para Rasul 17:7), Paulus dipaksa meninggalkan Tesalonika yang dikasihinya, karena itu ia menyuruh Timotius ke Tesalonika untuk menanyakan kesejahteraan dan keteguhan iman mereka (1 Tesalonika 3:2). Tidak berapa lama kemudian Timotius kembali kepada Paulus yang telah pindah ke Korintus dengan membawa laporan yang sangat menggembirakan 1Tesalonika 3:6) sesudah itu Paulus menulis surat pertama Tesalonika. ${ }^{15}$

Dunnet menjelaskan bahwa "bahwa menulis surat 1Tesalonika ini kepada orangorang Kristen yang berada dalam kesukaran dan yang dianiaya setelah kepergian Paulus (1 Tesalonika 2:14) sebagai penganti kunjungan pribadinya (1 Tesalonika 2:17,18) dan bersyukur kepada Allah atas berita mengenai pendirian oleh Timotius (1Tesalonika 3:610)." 16 Kemudian Drane menjelaskan ada lima hal yang melatarbelakangi Paulus menuliskan surat 1 Tesalonika yakni:

Pertama, ketekunan dan tanggung jawab yang dapat dijadikan teladan dalam iman kepada Kristus (1 Tes. 1:1-10). Kedua, adanya serangan oleh orangorang Yahudi dengan maksud menganiaya jemaat di Tesalonika (1 Tes. 1:6). Ketiga, adanya percabulan (1 Tes. 4:3-8). Keempat, perasaan ingin tahu bagaimana keadaan orang Kristen yang meninggal dan kedatangan kristus

\footnotetext{
${ }^{14}$ David A. Hubbard, The Wycliff Bible Commentary: Tafsiran Alkitab Perjanjian Baru volume 3 (Malang: Gandung Mas, 2001), 819

${ }_{15}$ J. Sidlow Baxter, Menggali Isi Alkitab 4 Roma-Wahyu (Jakarta: Yayasan Komunikasi Bina Kasih/ OMF, 2002), 143.

${ }^{16}$ Walter M. Dunnet, Pengantar Perjanjian Baru (Malang: Gandum Mas, 2005), 49
} 
yang kedua kali (1 Tes. 4:13-5:1-2). Kelima, kegagalan menghormati pemimpin-pemimpin jemaat (1 Tes. 5:12-13). ${ }^{17}$

Tulluan menjelaskan bahwa "Paulus hanya sempat melayani disana beberapa minggu dan pasti iman mereka belum kuat, oleh karena itu Paulus merasa gelisah mengingat saudara-saudaranya di Tesalonika yang begitu dikasihinya." 18 Penjelasan tersebut secara nyata dalam Alkitab membuktikan bahwa Paulus sangat menginginkan jemaat Tesalonika tetap teguh dalam iman, walaupaun tantangan penganiayaan yang mereka alami terhadap orang-orang Yahudi, namun mereka tetap menunjukkan keteguhan iman mereka kepada Kristus. Dari data-data di atas maka ada penulis menyimpulkan Surat 1 dan 2 Tesalonika ditulis oleh Rasul Paulus.

\section{Tempat Dan Waktu Penulisan}

Pertanyaan yang perlu dijawab adalah kapankah surat yang pertama kepada Jemaat di Tesalonika di tulis? Groenen memberikan waktu penulisan Surat ini pada tahun 49, sebelum Sidang di Yerusalem dan Jemaat itu sendiri didirikan pada tahun 39 M. ${ }^{19}$ Jika mau memberi keterangan secara kasar, jawabnya adalah: kedua surat ini ditulis tidak lama sesudah Paulus berada di Akhaya pada perjalanan kedua, jadi kira-kira tahun tahun $52 .{ }^{20}$ Surat Tesalonika yang pertama adalah surat pertama yang ditulis oleh Paulus kepada jemaat dan surat Tesalonika yang kedua ditulis hanya dua tiga minggu sesudahnya. Suratsurat itu ditulis di Kota Korintus pada tahun 51 dan 52, yaitu hanya 18 atau 20 tahun setelah kematian dan kebangkitan Yesus Kristus. ${ }^{21}$ Surat Tesalonika adalah surat Paulus

${ }^{17}$ Jhon Drane, Memehami Perjanjian Baru (Jakarta: BPK Gunung Mulia, 2015 ), 336, Bdg. dengan F. F. Bruce yang menjelaskan Paulus menulis surat 1 Tesalonika ini karena Paulus dan rekan-rekannya terburuburu meninggalkan Tesalonika, itu berarti orang-orang yang baru bertobat itu pasti akan mengalami penganiayaan, pada hal untuk menghadapi itu mereka belum siap, sebab Paulus tidak cukup waktu mengajarkan semua ajaran yang dia anggap sangat mereka butuhkan (Lih. : F.F Bruce, Ensiklopedi Alkitab Masa Kini Jilid II M-Z (Jakarta: Yayasan Komunikasi Bina Kasih/OMF, 2007), 468)

${ }^{18}$ Olla Tulluan, Introduksi Perjanjian Baru (Batu: Departemen Literatur YPPII, 2004),203

${ }^{19}$ Tulluan, Intoduksi Perjanjian Baru, 128

${ }^{20}$ Duyverman, Perjanjian Baru (Jakarta: BPK Gunung Mulia, 2017), 146

${ }^{21}$ J. Wesley Brill, Tafsiran Surat Tesalonika ( Bandung : Laskar Tuhan yang menantikan Tuhannya, 2008), 20. Lih. pendapat-pendapat berikut, Baxter menulis "semua bukti baik didalam maupun di luar Tesalonika menjamin bahwa surat-surat Tesalonika adalah buah pena. (Lih.: J. Sidlow Baxter, Menggali isi Alkitab 4 Roma-Wahyu...143). Selanjutnya Dunnet menulis "hanya surat-surat kiriman Tesalonika yang tidak menyebutkan jabatan resmi si penulis, hanya namanya saja (dan Siliwanus dan Timotius) yang dicantumkan pada bagian permulaan, agaknya dia menulis sebagai seorang teman pribadi dan penasehat rohaniah kepada anak-anak rohaninya yang sedang tertimpa kesusahan dan kesengsaraan. (Lih.: Walter M. Dunnet, Pengantar Perjanjian Baru...,49). Bavinck menulis "segera Paulus berjumpa kembali dengan Silas dan Timotius, dikirimkanyalah sepucuk surat ke Tesalonika (1 Tes. 1:1; 3:6).” (Lih.: J. H. Bavinck, Sejarah Kerajaan Allah Jilid II Perjanjian Baru (Jakarta: BPK Gunung Mulia, 1983), 280). Demikian juga Bruce menulis "kedua surat kepada Jemaat di Tesalonika ditulis atas nama Paulus, Silwanus dan Timotius, tetapi yang menulis sesungguhnya ialah Paulus. Walaupun digabungkan kedua temanya itu dengan dirinya, namun dalam 1 Tesalonika Paulus memakai kata "aku" (1 Tes.3:2,6); dalam 2 Tesalonika ditambahkannya tanda tangannya 
yang pertama, yang ditulis menjelang akhir tahun 52. Hampir semua ilmuwan Biblika setuju surat ini merupakan dokumen Kristen tertua yang masih ada. Dan pada hakekatnya sebagian besar surat bersifat surat pribadi, hanya dalam dua pasal terakhir berisi masalah doktriner."22

\section{Tujuan Penulisan}

Dalam surat Tesalonika Paulus memuji saudara seiman yang setia atas pengabdian yang kokoh kepada Kristus. Balchim menjelaskan alasan penulisan surat 1 Tesalonika ini disamping menulis surat yang isinya secara umaum bersifat menguatkan, Paulus juga mempunyai tujuan lain yaitu: ${ }^{23}$

1. Membela diri atas tuduhan palsu (1 Tesalonika 2:1-14)

2. menekankan perlunya sikap moral Kristen yang khas (1 Tesalonika 4:12)

3. Memperbaikin kesalah pengertiaan tentang kedatangan Kristus yang kedua kali (1 Tes. 4:13-18)

4. Mendisplin ketidak dewasaan dikalangan Jemaat muda (1 Tes. 5:12-22)

Paulus hendak menyatakan cinta kasihnya kepada orang Kristen di Tesalonika dan menguatkan hati mereka dalam penderitaaan mereka, serta membentulkan pemikiran mereka yang salah mengenai kedatangan Tuhan Yesus yang kedua kali. Mereka berdukacita sebab mereka beranggapan bahwa orang-orang kristen yang telah meninggal sebelum kedatangan Tuhan tidak mendapat bagian dalam kemuliaan kedatangan Tuhan Yesus kristus untuk jemaat-Nya.

\section{Penerima Surat}

Surat ini ditunjukan kepada jemaat orang-orang Tesalonika; ini berarti bahwa surat ini harus dibacakan di dalam pertemuan jemaat orang-orang Kristen Tesalonika, yang barang kali berkumpul dirumah-rumah untuk beribadat, karena pada waktu itu belum ada bangunan Gereja. ${ }^{24}$ Paulus menyatakan kepuasaannya saat mendengar kemajuan jemaat, dan sukacita ini muncul disepanjang surat. Ia merasa perlu menjawab tuduhan, mungkin

sendiri. Jadi 'aku' dalam 2 Tesalonika2:5 harus berarti dia” (Lih.: F.F. Bruce, Ensiklopedi Alkitab Masa Kini Jilid II $M-Z \ldots, 341)$ 2010), 31

${ }^{22}$ Bambang Subandrijo, Mengingkap Pesan-Pesan Perjanjian Baru (Bandung: Bina Media Informasi,

${ }^{23}$ John Balchim (Ed, Intisari Alkitab Perjanjian Baru, 78 (Bdg. pertama, Rasul Paulus ingin meluruskan kesalahpahaman yang ada dalam jemaat mengenai ajaran pengudusan hidup adalah kehendak Allah demi kehidupan mereka. Kedua, surat ini ditulis sebagai reaksi rasul Paulus terhadap kabar yang dibawa oleh Timotius dari jemaat Tesalonika. Ketiga, pertanyaan Timotius mengenai kematian (1 Tes. 4:113) (Lih. : Gladis Hunt, Pandangan Kristen Mengenai Kematian (Jakarta: BPK BPK Gunung Mulia, 2001), 243). Selanjutnya lihat juga pendapat Champman, menulis bahwa tujuan utama Rasul Paulus menulis surat Tesalonika ini adalah untuk menguatkan dan meyakinkan kemabali umat Kristen di Tesalonika. Tujuan penulisan surat ini 1Tesalonika ini adalah untuk meluruskan kesalahpahaman Jemaat atas surat Paulus. (Lih. : Champman, Surat-Surat Palsu, (Yogyakarta: Bina Media Informasi, 2004), 110)

${ }^{24}$ Dianne Bergant, CSA, Tafsiran Alkitab Perjanjian Baru (Yogyakarta: Kanisius, 2002), 371 
oleh para lawan Yahudinya, bahwa ia mencari keuntungan pribadi dan bersikap pengecut. Ia mendorong jemaat untuk bertekun, sekalipun mereka harus menghadapi perlawanan dan penganiayaan orang Yahudi. Ia menunjukkan keunggulan moralitas Kristen atas orangorang kafir, mungkin untuk menjaga mereka dari usaha orang-orang kafir yang mau mengembalikan orang Kristen yang baru bertobat pada kebiasaan yang lama mereka. Dan ia membetulkan kesalahpahaman Prousia. Oleh karena beberapa orang yang mereka kasihi yang telah meninggal, sementara beberapa yang lain jatuh oleh karena pada kemalasan, karena mereka percaya Tuhan segera datang. ${ }^{25}$ Paulus menasehatkan agar jemaat tetap terus bekerja dalam pengharapan mereka, menantikan kedatangan Prousia. Jemaat Tesalonika hampir seluruhnya terdiri dari orang-orang kafir, yang agaknya cenderung kembali menyembah berhala mereka. ${ }^{26}$

\section{KAJIAN EKSEGETIS SURAT 1TESALONIKA 5:18}

Dalam bagian ini, Penulis akan mengeksegese beberapa kata penting supaya mendapatkan kajian yang mendalam tentang teks, sehingga dapat memahami Perspektif Rasul Paulus tentang mengucap syukur dalam segala hal.

\section{Mengucap Syukur Adalah Perintah Allah (1 Tes. 5:18)}

Mengucap syukur adalah Perintah Allah bagi orang percaya, Kata "Mengucap syukur" dalam bahasa Yunani memakai kata $\varepsilon v \chi \alpha \rho \imath \tau \varepsilon \omega$ (eucharisteo) dengan kasus Verb imperative Present active 2nd person plural dari kata dasar $\varepsilon v \chi \alpha \rho ı \tau \varepsilon \omega .{ }^{27}$ yang memiliki arti give thanks (mengucap syukur, memberi syukur), be thankful (berterimakasih). ${ }^{28}$

Kasus ini merupakan suatu kata kerja yang berbentuk Perintah (imperative) yang dilakukan secara terus-menerus yang dari Paulus kepada Jemaat yang ada di Tesalonika. Tujuannya adalah agar hidup mereka sadar dengan apa yang mereka rasakan dihadapanNya dan penuh dengan ucapan syukur kepada Allah.

Dalam Versi Revised Standard Version (RSV) menyatakan bahwa mengucap syukur adalah "memberi terima kasih dalam sebuah keadaan." Terjemahan Lama (TL) mengatakan bahwa dan ucapkanlah syukur di dalam segala sesuatu, karena inilah kehendak Allah di dalam Kristus Yesus kepada kamu. ${ }^{29}$ Versi Firman Allah Yang Hidup (FAYH) mengatakan bahwa Apa pun yang terjadi hendaklah Saudara bersyukur, karena

\footnotetext{
${ }^{25}$ Donald Guthrie, Pengantar Perjanjian Baru Volume 2 (Surabaya: Momentum, 2009), 172,173

${ }^{26}$ Bambang Subandrijo, Meyingkapan Pesan-Pesan Perjanjian Baru, 31

${ }^{27}$ Strong's Number, Bible Works 7, CD-ROM 05-04-2017

${ }^{28}$ Strong's Number, Bible Works 7, 05-04-2017

${ }^{29}$ Strong's Number, Bible Works 7, 05-04-2017
} 
itulah kehendak Allah bagi Saudara sebagai milik Kristus Yesus. ${ }^{30}$ Versi Bahasa Indonesia Sehari-hari (BIS) mengatakan bahwa Dalam Segala keadaan hendaklah kalian bersyukur, sebab itulah yang Allah inginkan dari kalian sebagai orang yang hidup bersatu dengan Kristus Yesus. ${ }^{31}$ Penulis memahami bahwa mengucap syukur adalah merupakan suatu tindakan orang percaya untuk memberi syukur, mengucap syukur apa pun yang terjadi atau berterimakasih kepada Tuhan dalam segala keadaan.

Friberg mengatakan bahwa "mengucap syukur adalah menyatakan terima kasih atau memberi tentang suatu doa rasa syukur yang terutama pada makanan atau memberkati". ${ }^{32}$ Mengucap syukur itu berarti memberi suatu doa rasa syukur yang terutama dalam makanan atau bersyukur untuk memberkati. Newman mengatakan bahwa "mengucap syukur adalah berterima kasikah, memberi terima kasih, berterima kasih. Gingrikch menyatakan bahwa mengucap syukur adalah memberi terima kasih, memandang atau mengucapkan terima kasih", 33 Lebih di pahami lagi bahwa mengucap syukur adalah mengucapkan terimakasih. Dengan demikian dapat dipahami bahwa setiap orang percaya harus memberi syukur, mengucap syukur, dan dengan penuh ucapan syukur kepada Tuhan.

Aprilani mengatakan bahwa "mengucap syukur adalah hal yang berkenan kepada Allah". ${ }^{34}$ Ternyata mengucap syukur itu yang berkenan kepada Allah. Liem menjelaskan bahwa "Mengucap syukur adalah menjadi sikap dasar dari kehidupan beriman Jemaat."35 Dalam hal Mengucap Syukur ternyata menunjukkan sikap orang-orang yang beriman kepada Tuhan. Ferrcci menyatakan bahwa:
"bersyukur menunjukkan bahwa saluran komunikasinya sedang terbuka, sehingga ia tidak sombong (karena ia tahu bahwa membutuhkan orang lain) dan juga tidak merasa rendah diri (kerena ia tahu bahwa ia layak menerima apa yang patut diterimanya). Artinya adalah ia sanggup untuk melihat suatu nilai di dalam situasi aktualnya. Ia dapat menghargai apa yang baik di dalam hidupnya." $" 36$

Penyataan bersyukur ternyata karena jawaban doa yang sedang digumuli selama ini. Jadi Penulis berkesimpulan bahwa seseorang bersyukur karena terjadinya suatu hal atau peristiwa dalam hidupnya.

\footnotetext{
${ }^{30}$ Strong's Number, Bible Works 7, 05-04-2017

${ }^{31}$ Strong's Number, Bible Works 7, 05-04-2017

32 Barbara Friberg, Analytical Lexicon of the Greek New Testament (Grand Rapids: Baker House Publisher, 2000), 13491

${ }^{33}$ Frederick W. Danker, Shorter Lexsicon Of The Greek New Testament, Wilbur Gingrich, 2735

${ }^{34}$ Herdian Aprilani, Tafsiran Mattew Henry (Surabaya: Momentum, 2015), 495

${ }^{35}$ Liem Khiem Yang, Bertumbuh Bersama Dalam Iman (Jakata: BPK Gunung Mulia, 2012), 14

${ }^{36}$ Piero Ferrucci, Bagaimana Menjadi Orang Baik (Jakarta : BPK Gunung Mulia, 2009), 219
} 
Paul mengatakan bahwa "bersyukurlah kepada Allah walau apa pun yang terjadi". 37 Lebih di pahami lagi bahwa apapun yang terjadi tetap bersyukur kapada Tuhan. Candawasa mengatakan dalam bukunya bahwa "Mengucap syukur adalah wujud iman terhadap janji Tuhan: memberikan yang baik untuk orang mengasihiNya". ${ }^{38}$ Ternyata seseorang yang mengucap syukur karena wujud atau buah dari pada imannya terhadap janji Tuhan. Karena itu untuk dapat mengucap syukur seseorang harus memiliki kepekaan terhadap anugerah Tuhan yang masih disisakan bagi seseorang; bukan hanya menyadari kesulitan, kehilangan, penderitaan yang sedang di alami.

Yohan menyatakan "Pernakah seseorang berada dalam kesusahan: segala sesuatunya diambil sampai habis sama sekali tanpa ada yang disisakan sedikit pun? Tidak akan pernah! Jika demikian, maka ucapan syukur kita juga tidak akan pernah habis." 39 Penulis memahami bahwa sekalipun orang percaya di dalam kesusahan, bagi orang percaya mengucap syukur itu tidak ada batasnya. Dalam hal mengucap syukur itu merupakan suatu keharusan bagi orang percaya, namun masih banyak orang percaya yang sulit mengucap syukur dalam segala hal. Brill menjelaskan bahwa:

“orang kristen yang sungguh-sungguh mengucap syukur di dalam segala sesuatu. Mungkin ia tidak bersyukur karena suatu hal, tetapi didalam hal itu. Itulah kehendak Allah untuk kita sekalian. Mungkin seseorang berkata, “ mustahil orang hidup demikian." Namun, Tuhan Yesus sudah hidup demikian dan ia dapat hidup seperti itu didalam seseorang. Banyak orang Kristen yang tidak bersukacita dan mereka tidak berdoa dengan sepatutnya, malahan mereka lebih banyak bersungut-sungut. Mereka akan lupa kesetiaan Allah, tidak bersyukur atas kasih karunia Allah, tidak percaya akan janji Allah, dan takut sebab tidak menyadari bahwa Tuhan Yesus mengatur kehidupan mereka." 40

Dari pendapat di atas jelas bahwa orang yang sulit untuk bersyukur itulah sebabnya Tuhan menghendaki umat-Nya untuk bersyukur. Paulus mendorong Jemaat Tesalonika untuk melakukan apa yang harus dilakukan: bergembira (3:9), selalu berdoa dan bersyukur (1:2-3). Ia meminta mereka untuk melakukan hal-hal itu, karena semua itu merupakan kehendak Allah dalam Kistus Yesus. ${ }^{41}$ Oleh karena itu, sangat jelas bahwa Paulus juga mendorong orang percaya untuk tetap bergembira, berdoa dan bersyukur.

\section{Mengucap Syukur Dalam Segala Hal (1Tes. 5:18)}

${ }^{37}$ Paul Ellingworth, Surat-surat Paulus Kepada Jemaat di Tesalonika (Jakarta: Lembaga Alkitab Indonesia), 83

${ }^{38}$ Yohan Candawasa, Mendapatkan-Mu Dalam Kehilanganku (Bandung: Mitra Pustaka, 2005), 126

${ }^{39}$ Candawasa, Mendapatkan-Mu Dalam Kehilanganku, 127

${ }^{40}$ J. Wesley Brill, Tafsiran surat Tesalonika (Yayasan: Kalam Hidup), 96

${ }^{41}$ Dianne Bergant, CSA, Tafsiran Alkitab Perjanjian Baru (Yogyakarta: Kanisius, 2002),378 
Kata "segala hal" dalam bahasa Yunani memakai kata $\pi \alpha \varsigma$ (pas) dengan kasus adjective indefinite dative neuter singular. Kata ini berasal dari kata "panti." yang artinya semua segala sesuatu yang mencangkup secara keseluruhan. ${ }^{42}$ Jadi kasus ini adalah suatu kata sifat yang secara tidak langsung akan sedang dikerjakan. Itulah yang Paulus tegaskan kepada Jemaat yang ada di Tesalonika.Tujuannya adalah agar segala sesuatu yang hendak mereka alami, baik pun dalam keadaan kesulitan, penderitaan atau kejadian apapun, hendaklah hidup mereka tetap mengucap syukur senantiasa kepada Allah.

Kata "Segala hal" dalam Kamus Besar Bahasa Indonesia yang memiliki arti segalasegalanya semua, seluruh. ${ }^{43}$ Dalam Versi Firman Allah Yang Hidup (FAYH) mengatakan apa pun yang terjadi hendaklah Saudara bersyukur, karena itulah kehendak Allah bagi Saudara sebagai milik Kristus Yesus. ${ }^{44}$ Dalam Versi Bahasa indonesia sehari-hari (BIS) mengatakan Dalam segala keadaan hendaklah kalian bersyukur, sebab itulah yang Allah inginkan dari kalian sebagai orang yang hidup bersatu dengan Kristus Yesus. ${ }^{45}$ Penulis memahami bahwa segala hal atau segala yang terjadi, dan apapun keadaannya tetaplah bersyukur kepada Tuhan.

Timothy mengatakan bahwa "mengucap syukur dalam segala hal itu di artikan sebagai segalanya, segala macam, segala rupa, segala macam penyakit". 46 Mewman mengatakan mengucap syukur dalam segala hal itu adalah dari semua kebaikan. ${ }^{47}$ Dari penyataan ini mengucap syukur itu berarti dalam segala macam keadaan. Penulis mengatakan dengan hal di atas bahwa setiap orang percaya harus mengucap syukur dalam segala hal, apapun yang terjadi, dan apapun bentuk keadaannya.

\section{Mengucap Syukur Adalah Kehendak Allah (1 Tes. 5:18)}

Kata "kehendak Allah" dalam bahasa Yunani memakai kata $\theta \varepsilon \lambda \eta \mu \alpha$ (thelema) asal kata " $\alpha \tau o \varsigma$ " yang artinya akan. Dengan kasus noun nominative neuter singular. Kasus ini menunjukkan suatu kata benda yang sedang dikerjakan yang memiliki arti (kehendak-Nya, kemauannya, keinginan). ${ }^{48}$ Ini merupakan suatu kata benda yang bersifat netral (nominativ) bentuk tunggal. Ini adalah nasihat dari Rasul Paulus kepada Jemaat

${ }^{42}$ Strong's Numbers, Bible Works7, 09 Mei2017

${ }^{43}$ Tim Pustaka Phoenix, KBBI(Jakarta: Media Pustaka Pheonix, 2007), 762

${ }^{44}$ Strong's Numbers Bible Works7, 03 september 2017

${ }^{45}$ Strong's Number, Bible Works 7, 03 September 2017

${ }^{46}$ Timoty Friberg, Analytical Lexicon Of The Greek New Testament (Grand Rapisds: Baker House, 2000), 12299

\footnotetext{
${ }^{47}$ Barclay M. Newman, Jr., Aconcise Greek-English Dictionary of The New Testament...

${ }^{48}$ Strong's Numbers, BibleWorks 7, 09 Mei2017
} 
Tesalonika. Supaya mereka hidup seturut kehendak Allah, dalam kemauan Allah, dan keinginan Allah.

Kata Kehendak dalam kamus besar bahasa indonesia adalah kemauan, keinginan harapan yang keras. Kehendak adalah kemauan atau keinginan Allah. Dalam terjemahan Bahasa Indonesia sehari-hari (BIS) mengatakan dalam segala keadaan hendaklah kalian bersyukur, sebab itulah yang Allah inginkan dari kalian sebagai orang yang hidup bersatu dengan Kristus Yesus. ${ }^{49}$ Keinginan yang di maksud adalah Allah mengiginkan umat-Nya untuk hidup dalam kehendak-Nya. Newman mengatakan "Kehendak itu adalah Harapan, keinginan". ${ }^{50}$ Jadi Penulis menyimpulkan bahwa mengucap syukur adalah kehendak-Nya, keinginan dan harapan Allah kepada umat-Nya.

\section{KAJIAN TEOLOGIS PERSPEKTIF TENTANG MENGUCAP SYUKUR}

Kajian teologis didasarkan pada pendapat-pendapat para Theolog mengenai mengucap syukur, namun kajian ini tetap dibatasi pada konteks kajian eksegetikal teks. Dalam kajian teologis ini ada beberapa point yang dituliskan:

\section{Bersyukur Adalah Perintah Tuhan}

Setiap anak-anak Tuhan yang tahu mengucap syukur adalah orang yang percaya bahwa Tuhan itu baik. Hidup orang percaya tersebut apapun ia alami, kebaikan Tuhan itu tidak pernah meninggalkan kehidupannya, seperti yang Ia janjikan (Maz. 106:6; 136:1). Setiap orang percaya yang tahu bersyukur adalah orang yang tahu menghargai (berterimakasih) atas berkat-berkat yang ia terima dari Tuhan. Kata terimakasih mengandung pengertian bahwa orang percaya menghargai pemberian-Nya karena orang percaya mendapatkan kasih. Bersyukur menyadarkan orang percaya bahwa semua yang di terima dalam kehidupannya adalah kasih karunia Tuhan. Oleh karena itu muliakan Tuhan dengan ucapan syukur dari hati karena itu, teruslah mengucap syukur sepanjang masih hidup di dunia ini (Maz. 50:23).

\section{Bersyukur Berkaitan Dengan Segala Hal}

Setiap orang percaya harus mengucap syukur dalam segala hal. Ini berarti walaupun orang percaya sedang ditimpa masalah atau malapetaka, orang percaya tetap terus mengucap syukur. Hal-hal yang baik atau buruk, keberhasilan atau kegagalan, sakit atau sehat, dalam kelimpahan atau kekurangan, suka atau duka, adalah warna-warni dalam kehidupan manusia. Salah satu hal yang seharusnya menguatkan orang percaya adalah “

\footnotetext{
${ }^{49}$ Strong's Numbers, Bible works7, 03 September2017

${ }^{50}$ Barclay, M. Newman, Jr. Aconcise Geek-English Dictionary Of The New Testament..., 210
} 
Allah turut bekerja dalam segala sesuatu untuk mendatangkan kebaikan” (Roma 8:28), karena itu tetaplah mengucap syukur apapun keadaannya. Dalam Perjajian Lama, contohnya Yusuf tidak tahu kenapa saudara-saudaranya membencinya sampai ketahap mau membunuhnya. Yusuf yang awalnya adalah anak kesayangannya Yakub, akhirnya dikhianati saudara- saudaranya sendiri dan dijual ke dalam perbudakan di Mesir. Dari usia 17 sampai 30 tahun, hidup Yusuf tidak lepas dari masalah yang berakhir dengan dia dimasukkan kedalam penjara, karena difitnah oleh isteri Potifar yang genit. Yusuf buruk itu kelihatannya tidak berbaut salah, tetapi mengapa hal-hal yang buruk terus saja menimpa dirinya. jadian 50:20, Yusuf berkata, "Memang kamu memaksudkan semua itu untuk kebaikan, yakni memelihara hidup suatu bangsa yang besar." Yusuf harus menjalani semua kejahatan yang menimpanya yang akhirnya membawanya kedudukan sebagai orang yang paling penting di Mesir setelah Firaun. Tujuan dari "segala hal yang buruk yang dialaminya" adalah agar Yusuf berada di dalam posisi yang dapat dipakai Allah untuk menyelamatkan satu bangsa. Oleh karena itu, mugkin tidak tahu apa alasan di balik semua hal itu, mungkin tidak tahu apa alasan di balik semua hal yang buruk yang sedang menimpa diri, tetapi apakah orang percaya dapat menyakini bahwa sekalipun dalam situasi yang paling parah, Allah tetap berdaulat dan memengang kendali? Keyakinan inilah yang membuat orang percaya dapat mengucap syukur dalam segala hal. Jadi, alasan pertama mengapa orang percaya dapat bersyukur dalam segala hal adalah karena orang percaya menyakini bahwa Allah tetap berdaulat.

\section{Bersyukur Berkaitan Dengan Kehendak Allah}

Hidup dalam Kehendak Allah berarti menjalankan perintah-Nya atau mengutamakan kehendak-Nya dari pada kehendak sendiri. Stephen Tong menjelaskan "Ini merupakan keinginanan Tuhan, suatu hasrat yang begitu diutamakan oleh Kristus". 51 Lebih jelas lagi bahwa yang terutama didahulukan orang percaya adalah keinginan Tuhan. Oleh karena itu, hal-hal apa saja kehendak Allah bagi kehidupan orang percaya yaitu melakukan kehendakNya dan mampu mengucap syukur dalam segala keadaan apapun. Oleh karena itu, setiap orang percaya harus melimpah dengan syukur kepada Tuhan, Surat kolose 2:7

\section{IMPLIKASI}

Implikasi dari perspektif tentang Mengucap syukur dalam segala hal sangatlah penting untuk diterapkan kepada Orang percaya sebagai dasar dalam kehidupan sehari-

\footnotetext{
${ }^{51}$ Stephen Tong, Mengetahui kehendak Allah (Surabaya: Momentum, 2008), 150
} 
hari. Berdasarkan kajian eksegetis di atas ada beberapa implikasi penting yang perlu dipahami oleh orang percaya tentang mengucap syukur dalam segala hal berdasarkan 1Tesalonika 5:18.

\section{Mengucap Syukur Adalah Perintah Allah}

1Tesalonika 5:18 menjelaskan tentang mengucap syukur serta menasihati orang percaya dalam kebaikan dan pemeliharaan Tuhan dalam setiap keadaan, atau kejadian yang sedang dialami. 1Tesalonika 5:18 menjadi dasar pemikiran bagi setiap orang percaya untuk tetap mengucap syukur dalam segala hal. Mengucap syukur adalah perintah Allah artinya bahwa bukan kehendak manusia atau Pendeta. Namun kehendak Allah di dalam Kristus Yesus, Tuhan ingin sebagai anak Tuhan mengucap syukur atas semua berkatberkat-Nya. maka dari itu ketika orang pecaya mengucap syukur kepadaNya, orang percaya tersebut telah melakukan kehendak Allah.

Orang percaya mengetahui bahwa mengucap syukur adalah perintah Allah. Akan tetapi banyak orang percaya hanya mengetahui namun belum menerapkannya. Tulisan ini meningatkan orang percaya untuk terus belajar untuk melakukannya sehingga kebenaran itu tidak hanya sebatas pengetahuan saja akan tetapi dapat diterapkan dalam kehidupan sehari-hari.

\section{Mengucap Syukur Dalam Segala Hal}

1Tesalonika 5:18 menjelaskan tentang mengucap syukur dalam segala hal, artinya bahwa orang yang mengucap syukur dalam segala hal adalah orang yang senantiasa membangun dirinya kearah yang lebih baik. Melihat segala pada sisi yang benar, setiap kejadian yang ada entah baik atau buruk tidak melemahkan dia, namun selalu berdampak positif. Maka dari itu, ingatlah selalu ada hal untuk disyukuri, ketika orang percaya diberikan kesehatan mengucap syukur, ketika orang percaya masih bisa makan mengucap syukurlah, ketika orang percaya masih memiliki rumah untuk berlindung, teman yang masih mengasihi, bahkan ketika orang percaya masih diberikan nafas kehidupan, mengucap syukurlah. Seberapa apapun masalah, pergumulan selalu ada hal untuk di syukuri. Dengan demikian segala sesuatunya mendatangkan kebaikan "kita tahu sekarang, bahwa Allah turut bekerja dalam segala sesuatu untuk mendatangkan kebaikan bagi mereka yang mengasihi Dia" Roma 8:28. Dengan demikian orang percaya sedapatnya mengucap syukur dalam segala situasi atau keadaan apapun baik itu senang maupun buruk. Oleh karena itu, Orang percaya harus terus belajar dalam kebenaran Firman Tuhan, dan 
belajar mengenal rencana-rencana-Nya dalam berbagai macam masalah, persoalan yang sedang ditemui dalam hidup ini.

\section{Mengucap Syukur Adalah Kehendak Allah}

1Tesalonika 5:18 menjelaskan bahwa mengucap syukur adalah kehendak Allah, artinya bahwa Allah menghendaki orang percaya untuk mengutamakan keinginan-Nya dari pada kehendak sendiri. Oleh karena itu mengucap syukur adalah kehendak-Nya atau keinginanNya dalam kehidupan anak-anak-Nya. Banyak orang percaya sudah memahami dasar kebenaran Firman Tuhan bahwa Mengucap syukur adalah Kehendak Allah. Namun orang percaya justru belum melakukan dan menerapkannya dalam kehidupannya. Oleh karena itu, Berdasarkan pengamatan dan survei, penulis menemukan bahwa bukan karena baru belajar akan tetapi lebih mengutamakan keinginan hati dari pada Kehendak Allah. Dengan demikian, Orang percaya harus belajar untuk mengutamakan kehendak Allah, Jika telah belajar mendahulukan keinginan Allah, maka Orang percaya telah melakukan Kehendak Allah tersebut.

\section{PENUTUP}

Berdasarkan hasil paparan di atas, penulis menyimpulkan bahwa Perspektif Rasul Paulus Berdasarkan 1Tesalonika 5:18 dapat menjadi aplikasi bagi Orang percaya sebagai dasar untuk tetap mengucap syukur dalam setiap keadaan baik senang maupun tidak. Oleh karena itu, apabila perspektif ini diterapkan bagi kehidupanya akan menjadi dasar untuk tetap mengucap syukur dalam segala hal. Dengan memahami Perspektif Rasul Paulus tentang mengucap syukur dalam segala hal yang berdasarkan 1Tesalonika 5:18 akan membuat kehidupan Orang percaya memiliki pertumbuhan iman yang baik dan sehat. Setiap orang percaya harus mengucap syukur atas kasihNya, kesetiaan-Nya dan janji-Nya atas hidup umat yang telah menerima berkat-Nya. Mengucap syukur adalah sikap yang sangat baik, mengucap syukur adalah menyatakan rasa terimakasih kepada Tuhan. Ada pun hal-hal yang dituntut kepada anak-anakNya, agar setiap orang percaya harus untuk mengucap syukur bukan hanya pada senang saja tapi juga dalam setiap kejadian. Rasul Paulus menasihati agar setiap orang percaya harus mengucap syukur dalam segala hal, 1Tesalonika 5:18.

Mengucap syukur dalam segala hal, maksudnya adalah apapun yang dirasakan orang percaya akan hidupnya, baik sukacita dari Tuhan maupun juga dalam penderitaan atau kesusahan. Jadi dari setiap yang akan diterima orang percaya akan hidupnya memiliki 
keharusan untuk tetap mengucap syukur kepada Tuhan, karena Tuhan tidak membiarkan Umat-Nya yang terus bersyukur atas keadaannya. Oleh karena itu setiap orang percaya harus melihat kebaikan dan pemeliharaan-Nya, dan penuh ucapan terimakasih atas semua yang Tuhan berikan akan hidup ini. Oleh karena itu, setiap Orang percaya Orang percaya sebagai anak-anak Tuhan, harus memiliki gaya hidup sehari-hari untuk menerapkan perintah atau kebenaran Firman Tuhan dalam pribadi masing-masing. Mengucap syukur dalam segala hal, sebab itulah yang dikehendaki Allah di dalam Kristus bagi kamu, berdasarkan 1Tesalonika 5:18. Setiap orang percaya adalah harus mengucap syukur dalam situasi atau keadaan apapun. Dengan adanya tindakan mengucap syukur, itu berarti telah melakukan kehendak-Nya. Mengucap syukur adalah perintah dan kehendak Allah sehingga setiap orang percaya haruslah melakukannya dalam segala situasi. Dengan demikian, Orang percayaharus memperhatikan keinginan Allah artinya bahwa anak-anakNya harus hidup dalam kehendak-Nya bukan mengutamakan keinginan pribadi. Jadi mengucap syukur adalah kehendak Allah, di dalam Kristus Yesus bagi anak-anak-Nya.

Orang percaya memiliki pemahaman yang benar terhadap firman Tuhan, namun penerapannya untuk melakukan kebenaran firman tersebut masih belum melakukannya. Dalam kajian eksegetis dan teologis penulis menyimpulkan beberapa hal: mengucap syukur adalah perintah Allah, mengucap syukur dalam segala hal, mengucap syukur adalah kehendak Allah. Demikian dalam kehidupan Orang percaya seharusnya mengutamakan kehendak-Nya, sekalipun banyak masalah yang temui dalam hidup ini. Oleh karena itu, bukan berarti melupakan kehendak-Nya atau perintah Tuhan akan tetapi belajar untuk taat dalam kehendak-Nya. 


\section{DAFTAR PUSTAKA}

(Ed), J. B. (2012). Intisari Alkitab Perjanjian Baru. Jakarta: BPK Gunung Mulia.

Bavinck, J. (1983). Sejarah Kerajaan Allah Jilid II Perjanjian Baru. Jakarta: BPK Gunung Mulia.

Baxter, J. S. (2002). Menggali Isi Alkitab 4 Roma - Wahyu. Jakarta: YKBK.

Bergant, D. (2002). Tafsiran Alkitab Perjanjian Baru. Yogyakarta: Kanisius.

Bible Works 7. (n.d.). Strong's Number.

Brill, J. W. (2008). Tafsiran Surat Tesalonika. Bandung: Laskar Tuhan Yang Menantikan Tuhannya.

Bruce, F. (2007). Ensiklopedi Alkitab Masa Kini Jilid II M-Z. Jakarta: YKBK.

Candawasa, Y. (2005). Mendapatkan-Mu dalam Kehilangaku. Bandung: Mitra Pustaka.

Carothers, M. R. (2008). Kuasa Dalam Pengucapan Syukur. Jakarta: Kristen Injili Indonesia.

Champan. (2004). Surat-Surat Palsu. Yogyakarta: Kanisius.

Dahlenburg, G. D. (2003). Firman Hidup. Jakarta: BPK Gunung Mulia.

Danker, F. W. (n.d.). Shorter Lexicon of The Greek New Testament. Wilbur: Baker House.

Drane, J. (2015). Memahami Perjanjian Baru. Jakarta: BPK Gunung Mulia.

Dunnet, W. M. (2005). Pengantar Perjanjian Baru. Malang: Gandum Mas.

Duyverman. (2017). Perjanjian Baru. Jakarta: BPK Gunung Mulia.

Ellingworth, P. (n.d.). Surat-Surat Paulus Kepada Jemaat Di Tesalonika. Jakarta: LAI.

Ferruci, P. (2009). Bagaimana Menjadi Orang Baik. Jakarta: BPK Gunung Mulia.

Frieberg, B. (2000). Analitycal Lexicon of The Greek New Testament. Grand Rapids: Baker House Publisher.

Guthrie, D. (2009). Pengantar Perjanjian Baru Volume 2. Surabaya: Momentum.

Henry, M. (2015). Tahsiran Matthew Henry. Surabaya: Momentum.

Hubbard, D. A. (2001). The Wycliff Bible Commentary: Tafsiran Alkitab Perjanjian Baru Volume 3. Malang: Gandum Mas.

Hunt, G. (2001). Pandangan Kristen Mengenai Kematian. Jakarta: BPK Gunung Mulia.

Izaak, S. (2003). Firman Hidup. Jakarta: BPK Gunung Mulia. 
Maukar, F. (2008). Masalah Adalah Berkat. Jakarta: International Galilea Ministry.

Munthe, A. (2002). Firman Hidup. Jakarta: BPK Gunung Mulia.

Newman, B. M. (n.d.). Anconcise Greek-English Dictionary of The New Testament. Grand Rapids: Baker House.

Publishing, A. (2003). Salam Dan Doa. Jakarta: Do Business.

Subandrijo, B. (2010). Menyingkap Pesan-Pesan Perjanjian Baru. Bandung: Bina Media Infoemasi.

Tan, D. (2016). Sistematika Pembinaan Warga Jemaat. Manado: Yayasan Daun Family.

Tim Pusaka Phoenix. (2007). KBBI. Jakarta: Media Pustaka Phoenix.

Tong, S. (2004). Mengetahui Kehendak Allah. Surabaya: Momentum.

Tulluan, O. (2004). Introduksi Perjanjian Baru. Batu: Departemen Literatur YPPII.

Yang, L. K. (2012). Bertumbuh Bersama Dalam Iman. Jakarta: BPK Gunung Mulia. 